\title{
Relationship between Financial Structure and Financial Performance of Flag Carriers in Africa
}

\author{
Kristine Wambui Maina ${ }^{1}$, Dr. Tobias Olweny, Ph. D $^{2}$ \\ ${ }^{1}$ Post Graduate Student, School of Open and Distant Learning, Jomo Kenyatta University of Agriculture and Technology, Kenya \\ ${ }^{2}$ Lecturer School of Business, Jomo Kenyatta University of Agriculture and Technology, Kenya
}

\begin{abstract}
While airline profitability has remained a challenge over several years, the weakest performance identified by IATA reports was from airlines in Africa and Latin America. The main objective of this study was to determine the effect of leverage, liquidity, and asset tangibility on firm profitability of flag carriers in Africa. Stratified random sampling technique adopted reduced the working population of 23 firms to 4 firms namely Kenya Airways, Ethiopian Airways, Air Mauritius and South African Airways. Data was collected from each airline's website over a thirteen-year period between 2005-2017. The findings were that leverage had a significant effect that was either positive or negative depending on whether debt is financed by equity or by assets implying that airline managers should endeavour to target cost-efficient sources of capital. Liquidity and asset tangibility were observed to have no significant effect and had little to no explanatory power on financial performance in the selected African airlines. The study recommends implementing a collaborative effort using a tri-partite debt covenant between airline managers, lenders of capital and government. African governments and local lenders should step in to support their Flag carriers by reducing the gaps and costs associated with acquisition of debt and other sources of capital. Airline managers on their part should manage resources efficiently and be held accountable with periodic audits to ensure they are invested in sustainable levels of their airline's profitability.
\end{abstract}

KEYWORDS: leverage, liquidity, asset tangibility, financial performance, African airlines, flag carriers

\section{INTRODUCTION}

An effective financial structure is said to depend upon the decision by any business organization to use an appropriate balance of debt and equity to finance its obligations. Finance managers must evaluate how to efficiently, if at all, include shareholders' capital, or debt from third parties in the organization's financial structure. The gravity of this decision arises from the fact that there is a cost of capital and risk associated with each option that is acute to the long-run profitability of the company (Abeywardhana, 2017). Pires and Fernandes (2012) investigated the financial efficiency of a total of 42 airlines selected randomly in 25 countries using convenience sampling technique. The selection was done in 2001 immediately after the September 11 terrorist attack in the United States of America. The target airline's financial structure changes between 2001 and 2002 was measured using the Malmquist index. The study findings revealed that the extent of indebtedness in an airline's financial structure had an inverse relationship with its profitability depending on the fleet, firm size, and intangible assets. In other words, the lower the indebtedness, the higher the profitability and vice versa. In the same vein, another study which targeted 29 listed airports in 20 countries for a 29-year period between 1989 and 2017 established that total and long-term debt have an inverse relationship with return on assets but positively correlated with return on equity (Özcan, 2019).

In the airline industry, for example, financials are generally volatile which elucidates that profitability not assured. From purchasing of aircraft to fleet maintenance to information system and global distribution systems, substantial investments are undertaken by airline companies in carrying out their operations. Being a complex industry, it is imperative for airline mangers and shareholders to understand the major determinants that directly affect the financial structures (Pires \& Fernandes, 2012). It follows therefore that, as various industries have different facets, standard financial structure to be adopted must be tailored as per the requirements of that industry. (Mhlanga \& Steyn, 2017) argue that the airline industry, being atypical, is impacted by several macroeconomic factors to a larger extent than most industries. An assertion supported by Birnleitner (2013) who emphasizes that probing the macro environment of the organization is vital in identifying opportunities and threats. According to Machuki and Aosa (2011), uncontrollable factors in the macro environment indirectly shape an organization's ability to make decisions related to performance and strategy.

In a study dubbed financial structure in the world airline industry, Capobianco, and Fernandes (2004) used an 


\section{"Relationship between Financial Structure and Financial Performance of Flag Carriers in Africa"}

efficient frontier to present a managerial approach to the financial structure in the airline industry. A technique known as data envelopment analysis was used to determine what level of leverage was considered reasonable and how to substantiate that level. In large airline companies, where shareholder's capital was at least $40 \%$ of all funds, capital was used efficiently to generate returns on fixed assets. This performance depended on management in the company as country by country analysis did not prove to have any comparative advantages between the developed and developing economies. Companies that reduced their debt levels were observed to increase returns on assets over time. These findings were consistent with another study which used the Malmquist index to test for changes in the airlines' financial structure after the unexpected 9/11 attack in United States of America by sampling a list of 42 airlines from 25 countries. After this systematic risk occurred, airlines in America who decreased their fixed assets, using leaseback operations and increased portions of equity financing, displayed increased profitability compared to those that did not increase the ratio of equity to third party financing. (Pires $\&$ Fernandes, 2012). They conclude that during tumultuous and chaotic times, the most reasonable move to boost liquidity is to sell some of the airline's assets such as aircrafts.

In Turkey, a review on the relationship between working capital and firm's financial performance acknowledged that effective working capital management plays a crucial role in sustaining a business enterprise to the extent that if well managed, it could increase a firm's profitability. Pegasus Airlines and Turkish Airlines, who are both listed on the Istanbul Stock Exchange, evidenced this theory from an analysis of their 2009-2013 financial statements (Kendirli \& Kaya, 2016). Another example from Association of Asia Pacific Airlines (AAPA) for the period of 2010-2015 by Quang (2017) concluded that there was indeed a positive correlation linking between current ratio and financial leverage to profits before tax on assets and equity respectively. Therefore, airlines need to increase cash recoverability from sale of products and foster stronger cooperation with suppliers to enhance efficiency of working capital.

In terms of passenger kilometers flown, African aviation industry accounts for a meagre $2 \%$ of the total air transport traffic in the world. It is ironic that the continent has the highest accident rates. In 2010, western built jet hull accounted for $23 \%$ of the losses. This has compelled many passengers to switch to other international carriers. In Nigeria for instance, $98 \%$ of its population travelling by air use nonAfrican carriers because the country does not have a national carrier (Heinz \& O'Connell, 2013). According to O'Connell and Warnock-Smith (2012), Egypt Air's share of international trips marginally increased from 13.3\% in 2007 to $15.7 \%$ by the end of 2009 . Majority of these passengers were Egyptian which means that the carrier is not attracting many foreign passengers. As of 2010, $80 \%$ of the continent's capacity was carried by just $20 \%$ of the domestic carriers. The Yamoussoukro declaration which liberalized the continent's airspace has been implemented in different regional economic blocks within the continent at varying levels. Consequently, the much-needed continent-wide implementation has been left fragmented and heterogeneous. There are 40 cities across Africa with a combined population of close to one billion people. The Yamoussoukro agreement aims to act as catalyst for widespread connectivity within the continent and beyond, like it happened in the United States of America and Europe after deregulation (Schlumberger, 2002).

The African continent presents a unique set of challenges to its domestic carriers; key among them being poor aircraft utilization, high operational costs and low demand. The high costs are due to transport costs of jet fuel from refineries to various destinations in most of the continent's landlocked countries. The small size of African carriers' fleet is insufficient to enable them to negotiate favorable terms with the world's fuel major suppliers. Consequently, African carriers are unable to hedge fuel prices with their suppliers leaving them exposed to volatile price fluctuations (Ross \& Ytterfors, 2016). Low internet connectivity and low credit card penetration is another constraint hampering growth of African carriers. This has forced most of the airlines in the continent to incentivize travel agents by allowing them to charge their customers some commission of about $7 \%$ of the ticket price. Besides, most navigational service providers and airports are government-owned monopolies who charge considerably higher rates compared to airports in other parts of the world. In Johannesburg and Nairobi for example, landing charges for a 200 tonne aircraft costs around $\$ 2,500$ and $\$ 1,500$ respectively, whereas the landing charges for the same weight costs around \$500 in London's Heathrow airport (Heinz \& O’Connell, 2013).

African aviation industry has some of the oldest fleet of airplanes in the world. Most of the aircrafts are more than 10 years old, hence very costly to maintain in terms of poor reliability, increased fuel consumption, increased downtime and poor reliability. Aircraft utilization rates in the continent are the lowest compared to the rest of the world. The daily average aircraft utilization rate is 6.9 hours compared to Europe's 9.9 hours. The low rates are attributed to extended downtime of aging aircraft, poor scheduling, shortage of flight and maintenance personnel and night flying restrictions. African airlines also ply more routes per aircraft when compared to other international carriers. This reflects poor aircraft usage because state-owned airlines are preoccupied with desire to be seen operating in different markets and at the same time propagate their individual national pride (Hansman, 2014).

In Kenya, examination of the effect of privatization on the financial performance of the Kenyan aviation industry used Kenya's national career, Kenya Airways as a case study. 


\section{"Relationship between Financial Structure and Financial Performance of Flag Carriers in Africa"}

To achieve its objective, the study interrogated the theory surrounding privatization by reviewing impacts, objectives, concepts, methods, and experiences. Findings concluded that, after privatization, the relationship between liquidity and debt ratio to firm performance was high unlike before privatization when lower levels existed. Besides this, financial efficiency, income efficiency and asset turnover were also observed to have improved (Ochieng \& Ahmed, 2014). On the other hand, Kasomba and Omagwa (2020) investigated the influence of financial structure on the financial performance of domestic commercial airlines in Kenya. The study established that although domestic commercial airlines reported fluctuations in growth between 2012 and 2018, their financial performance has been on the downward trajectory over the same period. For instance, in 2018, the industry recorded a net loss of Kenya Shillings (Kshs.) 8 billion compared to Kshs. 7.1 billion losses recorded in the previous year, 2017. It was also reported that whereas debt financing hit a record high of Kshs 23 billion in 2018, the corresponding retained earnings declined disproportionately in the same period. Kasomba and Omagwa (2020) further noted that other studies exhibited little or no association at all between financial structure and firm performance in terms of domestic airlines in Kenya. Using a sample of 11 domestic commercial airlines operating in Kenya between 2012 and 2018, regression results showed that although lease financing had an insignificant influence on the financial performance of target domestic commercial airlines, share financing and retained earnings had a significant influence on the target firms' financial performance.

Over recent years, airline profitability has remainedI. a challenge steered by intensity in competition and challenges of doing business. A review of International Air Transport Association (IATA) annual 2016 report notes that 2015 was the first-year investors in the industry received a return on capital greater than the cost of capital, which is usually the norm in other industries. Over and above that, the report goes on to identify airlines from Africa and Latin America as the weakest as they posted huge after-tax losses while their counterparts in Asia and Europe posted moderate results and those from North America having the strongest performance. As a result, future profitability continues to remain at risk as projected increases in three main line items i.e., fuel, labor and maintenance will not augur well for airlines. To effectually monitor the airline industry's financial performance, recent literature places emphasis on taking additional measures than just paying attention to gross revenue and net income, (Teker, Teker, \& Güner, 2016). For example, in the findings of Mantin and Wang (2012), other variables namely service measure, productivity and operations strategy were found to be determinants of airline profitability especially prior to $9 / 11$ attack in the United States of America. Nevertheless, after the attack, the notable link ceased as passengers linked lack of better service to increased security measures or tended to be more tolerable to service glitches.

Financial structure decisions are major sources of information that can help flag carriers make key decisions concerning investment in aircraft purchases and choosing an optimal financial structure for the carrier. Besides, it gives the management an overall view of the current state of the carrier. Most studies indicate that most African national carriers' financial performance is poor (IATA,2015). These studies attribute the low performance to factors such higher liquidity risk, higher regulatory cost levels, operational inefficiencies, inadequate capitalization, and low credit rating. However, the financial structure issues, its relevance in as far as firm value is concerned or its linkage with carrier profitability as well as the determinants of financial structure specific to the flag national carriers in Africa is not properly addressed. This study is therefore intended to bridge this gap by comparing the effect of leverage, liquidity, and asset tangibility on profitability of target flag carriers in Africa.

\section{MAIN OBJECTIVE}

The aim of this study was to endeavour to ascertain the effect of financial structure on the financial performance of the flag carriers in Africa.

\section{A. Specific Objectives}

i. To establish the effect of leverage on firm profitability

ii. To examine the effect of liquidity on firm profitability

iii. To determine the effect of asset tangibility on firm profitability

\section{THEORETICAL REVIEW}

\section{A. Capital Structure Irrelevance Theory}

In a perfect market environment where it is assumed that taxes and transaction costs do not exist, Modigliani and Miller (1958) theorized that firms operate in a homogenous risk environment. It also assumes that the dividend pay-out ratio for firms is $100 \%$ with investors being able to lend and borrow money at the same interest rate that is comparable to the rate being offered by corporates. The theory also assumes that financial structure has no effect on the firm's financial distress. Modigliani and Miller (1958) argued that a firm's financial distress is caused by a combination of cost of capital represented by business risk and the firm's earnings capacity denoted by return on assets, and not consequentially by how the firm is financed. The implication is that firms that operate within the same industry or business environment for that matter usually possess similar risk characteristics and therefore have identical earning potential.

Theorists argue that such firms enjoy equal market values regardless how they are financed. And in case they exhibit dissimilar market values, investors who in this case can borrow and lend at the same rate of interest as corporates will be compelled to engage in arbitrage activities. This involves selling the securities of the overvalued firm which in this case could be their firm and buying securities of 


\section{"Relationship between Financial Structure and Financial Performance of Flag Carriers in Africa"}

undervalued firm. This exercise is commonly known as investment switching in most finance literature. This creates artificial demand for the securities of an undervalued firm while reducing the demand of securities of the overvalued firm. When this happens, the market valuation equilibrium is restored. However, this theory has been criticized since it assumes that the market is perfect. Besides, the authors have assumed that each firm falls under a specific risk class, with similar income regardless of its geographical location (Jensen, 2005). Stiglitz (1969) was among the first scholars to disagree with this assumption. The scholar argued that this contention was not realistic because in the real world, business enterprises do not operate in the same business environments. In addition, the author disagrees with the assumption that individuals can borrow funds at the same rate as corporates. The author argued that in practice, the limitations toward the market rates for individuals when borrowing can never be same with the firms.' In this regard, the author held that the assumption of home-based leverage is not realistic and sustainable.

Regarding the methodology, Frank and Goyal (2003) criticism of the theory contend that is simply anchored on an abstract mathematical model which does not include data collection and analysis methods used to arrive at the conclusion. Recent approaches in financial structure literature including this study mainly use a quantitative approach of data collection and as opposed to a less qualitative approach to empirically test the modern theories (Albers, 2017). It is worth noting that despite all these imperfections, and the theory's failure to provide normative statements of practical relevance," Jensen and Meckling (1976) considers Modigliani and Miller's contribution to financial structure theory "path breaking". Be as it may, Frank and Goyal (2003), argue that while the Modigliani-Miller theorem is not very clear in outlining how firms finance their trading activities, it has managed to find a justification why financing may matter. Miller (1988) also noted that in general the Modigliani-Miller theorem has been widely accepted and has become the bedrock for modern finance theories.

This theory is relevant to this study because it provides a non-biased view of the relationship between financial anatomy and firm performance variables used in the study. By arguing that financing decisions are irrelevant to the firm, this theory offers a neutral platform to undertake a keen empirical analysis of this relationship within the targeted population.

\section{B. Trade-off Theory}

This above theory may be considered as the most dominant of all the financial structure theories. The theory claims that for a firm to achieve optimum financing mix it ought to balance gains and losses of debt financing. This theory which is a culmination of research work of Modigliani and Miller (1963) came into being to address the heavy criticism many critics levelled against the earlier theory promulgated by Modigliani and Miller (1958) on capital structure irrelevance theory which argued the mix of debt and equity in a firm's financial was inconsequential. Modigliani and Miller (1963) argued that by acknowledging that in the real-world taxes do exist, arbitrage activities are not always sustainable, thus financial structure indeed affects the corporate market value.

By incorporating the impact of taxes and relaxing the assumption that arbitrage exists, Modigliani and Miller (1963) contend that interest on debt which is a tax allowable expense will provide the levered firm with extra cash flows. Consequently, the market value of the firm will increase. The trade-off theory further argues that in situations of permanent debt whose implication includes constant cost of debt and static marginal tax rate, highly indebted firms have more market value than less indebted firms. This situation is attributed to the present value of interest tax savings associated with debt financing. Jensen and Meckling (1976) agency costs theory contributed to the trade-off theory hypothesis by suggesting that even though debt has some advantages to the firm, the theory had its undoing which is associated to agency costs. Agency costs arise due to the principal-agent conflicts that usually exist between the shareholders, debtholders and firm managers. Management may sometimes overlook a firm's interests to pursue their own interests and waste an organization's free cash flows by investing in sub-optimal investments. Shareholders may also engage in unprofitable investment ventures on the other hand simply because of their limited liability to the firm. To cushion the firm from potential losses that may arise from such activities, creditors may introduce debt covenants and restrictions. These mechanisms constitute additional expenses in form of agency costs to the business organization that have the potential of offsetting the benefits associated with debt financing, hence reducing firm value.

Myers (1977) came up with bankruptcy costs dimension. The theory suggested that although debt financing is beneficial to the firm through tax savings, these benefits are not infinite. The author argued that besides agency costs, debt financing exposes the firm to bankruptcy risk. When a firm faces such risk, chances of defaulting on debt repayment are high. Myers (1977) theorized that when a firm resort to more debt financing, its financial risk increases because equityholders get less motivated to pump in more capital to the firm. The firm will be under pressure to a higher rate of return to its stockholders in terms of dividend pay-out ratios to compensate them for bearing more risk. Debt holders also become less enthusiastic to supply goods on credit or may demand high rates of interest on debt. This further increases the extent at which cash flows out of the firm. A combination of the theoretical effects of bankruptcy risk and agency costs enabled theorists to conclude that the tax savings benefits attributed to debt financing are offset by the present values of agency and bankruptcy costs. The theory claims that the higher the debt, the higher the firm value. However, at a 


\section{"Relationship between Financial Structure and Financial Performance of Flag Carriers in Africa"}

certain point any further increase in leverage increases agency costs as well as bankruptcy costs whose net effect is reduction in firm value.

Contrary to the financial structure irrelevance theory, the above trade-off theory supports the idea of having a financial structure with moderate gearing levels. Furthermore, it reasonably proves the existence of an optimum financial structure that business organizations strive to achieve and maintain so that they can maximize shareholders wealth (Ghazouani, 2013).

Pontoh and Budiarso (2018) argued that a valuemaximizing organization are not likely to encounter financial distress challenges hence they should maximize use of debt financing.

It is worth noting that trade-off models exist in different variations. Auerbach (1985) for instance, came up with and tested the adjusted trade-off model. This model concluded that risky and fast-growing companies should borrow less. Anginer, Mansi, Warburton and Yildizhan (2015) study with numerous rich specifications argued that financial structure depends on management's reputation, possibilities of take-over and restrictions contained in the debt-contracts. None of these theoretical and empirical developments, however, have succeeded in fully replacing the traditional version. Most studies still rely on the original assumptions mentioned above when experimenting with the trade-off theory.

Because of the trade-off theory, Modigliani, and Miller (1963) assert that the benefits attributed to debt financing is primarily associated with the tax savings that arise since interest payment is a tax allowable expense. Myers (1977) combined this popular model with the bankruptcy cost theory attributed to Kraus and Litzenberger (1973) and Scott (1976) giving rise to the classic static trade-off theory. According to this theory, bankruptcy costs contribute significantly to the costs of debt. These costs include legal and administrative costs of running a firm, subtle costs due to loss of a firm's reputation among its customers, loss of trust among staff and creditors due to uncertainties in business. From a cost-benefit analysis point of view, the immateriality of bankruptcy costs cannot offset the value of tax savings associated with debt financing. For this reason, the agency costs model promulgated by Jensen and Meckling (1976) is also considered.

The scholar then holds that the trade-off theory is relevant to this study because it provides an explicit understanding of the interrelationship between leverage and firm value especially because of the tax savings enjoyed by firms associated with borrowing. In addition, the theory introduces both agency and financial distress costs and shows the negative effect that financial structure may have on the firm when agency costs associated with borrowing are increased.

\section{Pecking Order Theory}

The pecking order model was developed by Myers (1984). According to this theory, business enterprises prefer internal sources of financing over external sources. In case there is dire need for firms to seek external financing, they would give preference to debt over equity. The theory emphasizes the fact that equity financing will always be considered as a last resort. The theory also contends that firms do not have predetermined set ratios for debt to equity proportions in their capital structures that may be construed optimum due to information asymmetry. Firms generally adopt a conservative approach when making dividends or use of debt financing decisions aimed at maximizing firm value.

The pecking order theory has been supported by many academicians such as Dada and Ukaegbu (2015) study on listed firms in Nigeria. One aspect synonymous with this theory is that profitable firms will always prefer internal sources of financing as opposed to taking up more debt or equity even though debt may be considered cheaper than equity when certain proportions are met. Myers (1984) suggested that information asymmetry issue affects firm value shareholders wealth maximization. This argument was supported by Fama and French (2002) who established that less levered firms were more profitable than more levered firms. Frank and Goyal (2003) argued that big firms tended to accumulate more debts in order to be able to support payments of dividends to their shareholders while small firms tended to behave contrarily.

In contrast with the trade-off theory, the pecking order theory considers interest tax savings and the possibility of firms facing bankruptcy. The theory argues that debt ratios are adjusted accordingly when external financing is needed (Ghazouani, 2013). This scenario may lead to the imbalance between internal cash flows and real investment opportunities (Shyam-Sunder \& Myers, 1999). This means that the firms that can borrow more debt are those whose investment needs exceed internally generated funds. Each firm's leverage ratio is generally a reflection of that firm's cumulative requirement for external sources of funds. Profitable firms with limited chances of growth tend to use their cash surplus or free cash flows to service debt rather than repurchasing shares. The theoretical implication of the pecking order theory is that there is a clear hierarchy of financing options available to business organizations. However, the theory does not suggest any well-defined target debt ratio as is the case with the tradeoff theory. The theory encourages businesses to prefer use of internal sources of finance over external sources that encapsulate equity and debt aimed at preserving the value and stability of the firm. The implication is that high debt levels in a firm's financial structure has a negative effect on its value and increases the chances of financial distress. In other words, high debt levels may lead to bankruptcy and the business may close shop (Jibran, Wajid, Waheed, \& Muhammad, 2012). 


\section{EMPIRICAL REVIEW}

\section{Financial Leverage and Financial Performance}

Financial leverage is the extent to which a firm uses fixed-income securities such as preferred equity and debt. The more debt financing a firm uses, the higher its financial leverage which is associated with high interest payments. This has a negative effect on the firm's profitability. As a result, risk to shareholders return is increased. A company should therefore keep its optimum financial structure in mind when making any major financing decisions so that any increase in debt or preferred equity should be geared towards increasing the value of the firm (Ahmed et al., 2018).

In the United States of America, Cole et al., (2015) conducted a study on thirty firms representing three sectors namely: industrial, healthcare, and energy sectors. The data was collected over a 10-year sample period between 2003 and 2014 from secondary sources namely annual reports and Yahoo Finance. This translates to 300 observations per sector. The sample of the target firms were randomly selected from the three different sectors using a security or rather stock screener. The study findings showed that financial structure appeared to have a negative association with return on assets in all the three sectors. This suggests that firms sought alternative financing, as they sacrificed potential performance by debt financing. However, the interrelationship between net profit margin and financial structure differed from one sector to the other. In the industrial sector, the relationship was positive while in the energy sector it was negative. Finally, in the health sector, there was no relationship. These findings suggest that firms in the industrial and healthcare sectors should finance their operations with debt thus agreeing with Modigliani and Miller (1963) capital relevance theory. In addition, those firms in the energy sector should seek alternative financing, an argument which is in tandem with the pecking order theory. The study also established that financial structure had no relationship whatsoever with security price in all the three targeted sectors. This implies that firms interested in financing their operations using debt financing can do so without necessarily sacrificing future stock market performance. This contention agrees with Modigliani and Miller (1958) capital irrelevance theory (Cole, Yan, \& Hemley, 2015).

Another study employed panel data techniques on banks in Sub-Sahara Africa to examine the if there was a link in the independent and dependent variables used in the study. Performance measures used in the study were: return on assets, return on equity and net interest margin. Using the Levin-Lin-Chu and Im-pesaran-shin unit root test, the study established that all the variables used in the study were stationary in levels. The study theorized existence of negative relationship between financial structure and bank performance. However, the study concluded that financial structure does not determine bank performance, but it is the other way round. Purposive sampling technique was used to select the sample of banks in the study involving 1050 observations (Anarfo, 2015).

\section{Liquidity and Firm Performance}

According to Waswa, Mukras and Oima (2018), liquidity of an asset means how fast or quickly that asset can be transformed into cash. When referring to firm liquidity, it means the ability to meet its short-term maturing obligations. It is usually measured using different ratios common among them being the current and the quick (or acid-test) ratios. Firm performance or profitability may be described as the firm's ability to generate income which surpasses its liabilities. Firm performance is usually measured using different ratios such as return on assets and return on equity. Efficient liquidity management involves proper planning and controlling of current assets and current liabilities. This is aimed at minimizing the risk of being unable to settle short-term maturing obligations when they fall due.

A comparison pitying the financials of high-levered against low-leverage firms in North America for the period 2000-2005 was done. The study findings showed that highly levered firms had higher return on equity values than low leveraged firms. Highly-levered firms had lower current and quick ratios compared to the low-levered firms. The study further revealed that although highly levered retailers tended to suffer low returns measured in terms of all the three profitability measures namely: return on assets, profit margin and return on equity, results for the highly levered wholesalers were mixed. While the highly-levered wholesalers recorded lower profit margins and lower return on assets, they recorded higher returns on equity compared to the other wholesalers. The higher and lower returns on assets equity values respectively imply that the equity values are too depressed compared to asset values in these firms. The stock values on the other hand are so low that net income finally seems higher when compared to their equity values. The study concluded that although both financially distressed retailers and wholesalers' groups suffer in terms of profitability and liquidity; the extent of loss experienced by the highly levered wholesalers is higher in the securities market when compared to the highly levered retailers. The study sampled wholesalers and retailers in the United States of America whose financial statements were posted on the Compustat database between January 1, 2000 and December 31, 2005 (Kaya, 2014).

Svitlík and Poutník (2016) studied investigated whether there existed correlation between liquidity and profitability in the Czech Republic for the period 2003-2013. A sample of 400,304 firm-years observations was used during the period under review. The selection criteria involved joint stock and limited liability companies only. Firm-years with missing, zero, or negative values regarding any of the study variables was excluded. Financial and insurance sector firms were also excluded from the study because they have different business characteristics. Secondary data for analysis was obtained from the Bureau van Dijik and Amadeus 
database. Time series and cross-sectional analysis was used to analyze data. The study could not confirm the level of significance of the correlation between selected liquidity ratios and return on assets albeit showing significant relationship between working capital turnover and return on assets for most of the time thereby supporting a lack of statistical significance between current and quick ratios and return on assets for about $50 \%$ of the targeted economic sectors for any investigated year. It then concluded that in case any relation existed between liquidity and firm profitability in the Czech Republic, that correlation could only be weak. In Jordan, Warrad (2015) study investigated the effect of current ratio on Jordanian Real Estate sector firms net profit margin over a 4-year period 2005- 2008 also concluded that there was no significant relationship between current ratio and ratios of the firms' net profit margin. TheII. study utilized secondary data of target firms listed on the Amman Stock Exchange during the period under review.

\section{Asset Tangibility and Firm Performance}

The effect of the composition of a firm's assets and how they explain its financial structure is an ongoing debate. Tangible assets are generally more liquid than intangible assets. Therefore, tangible assets have a higher second market value, and in case of bankruptcy these could be quickly and easily sold. Furthermore, ownership of tangible assets should give companies with such assets an increased debt capacity. The extent with which tangible assets are either negatively or positively associated with debt is not clear (Mwaniki \& Omagwa, 2017). They also sought to assess the effect of the asset structure on the financial performance of firms. The study targeted the commercial and service sector firms listed in the Nairobi Securities Exchange in Kenya. Data was collected from secondary sources (annual reports of the target firms). A census survey was done on all the listed target firms for the 5-year period, 2010-2014. Descriptive research design was used to explain the causal effect that existed between the study variables. Using multiple regression analysis, the statistical results indicated that asset structure had a significant positive correlation with the targeted firms' financial performance. To be precise, the results showed that long-term investments, and Property, Plants and Equipment have a statistically significant relationship with financial performance. However, current assets and intangible assets have a statistically insignificance association with financial performance.

In Indonesia, a study was commissioned to analyze the effect of asset structure on firm size and firm value. A sample of thirty-four real estate firms listed in Indonesia Stock Exchange for the period 2010-2014 was used. Using descriptive research design, the study findings revealed that asset structure had a positive influence on firm value. The study further established that with financial structure as a control variable, there was no indirect link between asset structure and firm value (Setiadharma \& Machali, 2017).
Similar findings were exhibited by Pouraghajan, Malekian, Emamgholipour, Lotfollahpour and Bagheri (2012) study of some 400 firms listed in Iran's Tehran Stock Exchange between 2006 and 2010 involving 12 industrial groups. Convenience sampling technique was used to settle on the target population and the subsequent sample size. The study sought to determine whether capital structure influences the financial performance of an organization. Using descriptive research design, study findings revealed that debt ratio was negatively correlated with firm performance. However, firm size, asset turnover, growth opportunities, and asset turnover had a significant negative relationship with firms' financial performance. Besides, firm age had an insignificant link with both return on assets and return on equity.

\section{METHODOLOGY \\ Research Design}

A research design may be defined as the blueprint for addressing the specific objectives of a study. In the field of research, different research designs are applied to different types of studies (Rahi, 2017). For this study, descriptive research design will be used because the study sought to determine the causal relationship between financial structure and financial performance of the targeted firms (Dunlock, 1993).

The study will use debt equity ratio to represent leverage, current ratio will be used as proxies for liquidity while fixed assets turnover was used as proxies for asset tangibility. These three ratios constituted the independent variables used in the study. Return on equity, on the other hand were used to represent the dependent variable. Javed et al., (2014) adopted a similar design while studying the same causal relationship by applying it on firms listed in Pakistan.

\section{Target Population}

In the case of this study, the population will comprise of all the 40 airlines as indicated in Table I. below.

Table I: Target Population

\begin{tabular}{lc}
\hline Region & Flag Carriers \\
\hline North Africa & 12 \\
Southern Africa & 7 \\
West Africa & 6 \\
East Africa & 12 \\
Central Africa & 3 \\
Target Population of the Study & $\mathbf{4 0}$ \\
\hline
\end{tabular}

Source: AFRAA 2018

\section{Sampling Frame}

Sampling technique may be defined as the process by which the subjects or elements in the sample will be selected (Mulry et al., 2006). Stratified random sampling technique was used to divide the target population into mutually exclusive regions namely: North, Southern, West, 


\section{"Relationship between Financial Structure and Financial Performance of Flag Carriers in Africa"}

East and Central Africa regions. The researcher will finally use convenience sampling technique to select flag carriers from each region based on the available secondary data from each firm's official website over the last 13-year period 20052017. Regions with incomplete data sets were excluded. The outcome of the samples will be as follows:

Table II: Regional Classification of Flag Carriers in Africa

\begin{tabular}{ll}
\hline Region & Flag Carriers \\
\hline North Africa & 6 \\
Southern Africa & 6 \\
West Africa & 4 \\
East Africa & 6 \\
Central Africa & 1 \\
Actual Working & \\
$\begin{array}{l}\text { Population of the Study } \\
\text { Excluded due to no data }\end{array}$ & $\mathbf{2 3}$ \\
Excluded due to limited & 16 \\
data Sample Flag & 3 \\
$\begin{array}{l}\text { Actual Sarriers for the Study } \\
\text { Caty }\end{array}$ & $\mathbf{4}$ \\
\hline Source: Author's Compilation 2019
\end{tabular}

Source: Author's Compilation 2019

\section{Choice of Model}

For this research, the author discerned that the Pooled Least Squares models' inherent nature to pool variables together neglecting the cross section and time series nature of the data would lack explanatory power and thus opted to dismiss it. Consequently, to better account for individual traits among the variables, the researcher focused on the application of other two popular panel data analysis models for her study namely the Fixed Effects Model and Random Effects Model.

The fixed effect model uses ordinary least squares principles on group specific "fixed effects" that may be unobserved to help us remove any bias caused by them even if they are not included in the data. In the opinion of (Mummolo \& Peterson, 2018), it is applicable with different kinds of multi-level data therefore it is frequently utilized used in causal inference because it is conceivably able to provide unbiased estimates on the grounds that certain assumptions are valid. It is notable however, that the model also contains some limitations as causal relationships may be inferred from weaker assumptions (Imai \& Kim, 2019). Specifically (Hill, Davis, Roos, \& French, 2019) outline twelve weakness of the fixed effect model like unobserved heterogeneity, imprecise interpretations of coefficients and imprudent comparisons with cross-sectional models, among others.

The Fixed Effect regression analysis equation for Return on Equity, ROE can be stated as follows:

$$
R O E_{i t}=\alpha+\beta_{1} D E R_{i t}+\beta_{2} C R_{i t}+\beta_{3} A T O_{i t}+F_{i t}+\varepsilon_{i t}
$$

$\mathrm{DER}_{\mathrm{it}}=$ Debt to Equity Ratio for the period 2005 to 2017

$\mathrm{CR}_{\mathrm{it}}=\quad$ Current Ratio for the period 2005

to 2017

$\mathrm{ATO}_{\text {it }}=$ Asset Turnover for the period

2005 to 2017

$\mathrm{ROE}_{\mathrm{it}}=$ Return on Equity ratio for the period 2005 to 2017

$\beta_{1}, \beta_{2}, \beta_{3}$ are regression coefficients

$\mathrm{F}_{\mathrm{it}}=$ Specific intercepts that capture heterogeneities across entities

$\varepsilon_{\mathrm{it}} \quad=\quad$ The error term

Random Effects model uses Generalized Least Square or Error Component Model (ECM) on the assumption that the individual traits of a random variable are uncorrelated with the explanatory variables. The random effects estimator should be scrutinized to ensure that it does not lead to any non-spherical error variances i.e variance of the error terms is constant and remains best linear unbiased estimator. Random Effect model can be used in hierarchical data according to draw differences from different population whose model parameters are random Although the model is widely used, one of its greatest disadvantages as pointed out by Hill et al., (2020) is that it requires more convolution to satisfy presumptions in the real world compared to the fixed effect model.

The modified equation (I) stated above can be restated as follows:

Random Effects regression analysis equation for Return on Equity, ROE

$$
\begin{gathered}
R O E_{i t}=\alpha+\beta_{1} D E R_{i t}+\beta_{2} C R_{i t}+\beta_{3} A T O_{i t}++Z_{i t} \gamma+ \\
\left(F_{i t}+\varepsilon_{i t}\right)
\end{gathered}
$$

Where:

$\mathrm{DER}_{\text {it }}=$ Debt to Equity Ratio for the period 2005 to 2017

$\mathrm{CR}_{\text {it }}=\quad$ Current Ratio for the period 2005 to 2017
$\mathrm{ATO}_{\text {it }}=$
Asset Turnover for the period

2005 to 2017

$\mathrm{ROE}_{\text {it }}=$ Return on Equity ratio for the period 2005 to 2017

$\beta_{1}, \beta_{2}, \beta_{3}$ are regression coefficients

$\mathrm{Z}_{\mathrm{it}} \gamma=$ Time invariant factors observed that cannot be estimated by fixed effects

$F_{i t}+\varepsilon_{i t}=$ Unobserved individual specific effects for each variable and the random error term

\section{RESULTS AND DISCUSSIONS}

\section{A. Descriptive Statistics}

It is customary for statisticians to use mean and standard deviation to measure and explain variability in a sample or population. These two measures of central tendency are popular as they can be computed easily and are simple to comprehend. According to Table III below, most of 
the independent variables had low standard deviations. This meant that the observations sampled had little variations from the observed means. The independent variable which had the highest mean of 1.18 , median of 1.08 and a standard deviation of 0.45 was asset turnover (ATO). The next highest mean was the current ratio $(\mathrm{CR})$ with a value of 0.83 , median of 0.83 and a standard deviation of 0.33 . The independent variable ROE had a mean of 0.18 , median of 0.15 and a standard deviation of 0.81 . These low deviations suggested that the sampled airlines have similar risk profiles, and the means of these independent variables ratios was the best measure of central tendency with minimal error in the prediction of any one value in the sampled airline dataset.

The exception was the debt to equity (DER) ratio which was observed to spread over a large range of values ranging between -17.47 and 4.21. Further, the ratio appeared negatively skewed as shown by its standard deviation of 2.88 , mean of 0.71 , median of 1.04 and skewness of -4.95 . This gap is understandable as the airline industry is known to be highly capital intensive with seasonal cash flows by nature yet at the same time those very airlines are required to generate enough income to manage and pay off those multitude of liabilities.

Table III: Descriptive Statistics on the Variables

\begin{tabular}{lllll}
\hline Description & ROE & DER & CR & ATO \\
\hline Mean & 0.18 & 0.71 & 0.83 & 1.18 \\
Median & 0.15 & 1.04 & 0.83 & 1.08 \\
Maximum & 4.32 & 4.21 & 1.66 & 2.60 \\
Minimum & -2.07 & -17.47 & 0.38 & 0.59 \\
Std. Dev. & 0.81 & 2.88 & 0.33 & 0.45 \\
Skewness & 2.01 & -4.95 & 0.64 & 0.95 \\
Kurtosis & 15.81 & 31.90 & 2.90 & 3.58 \\
Jarque-Bera & 390.38 & 2022.94 & 3.52 & 8.47 \\
Probability & 0.00 & 0.00 & 0.17 & 0.01 \\
Sum & 9.23 & 36.87 & 43.33 & 61.48 \\
Sum Sq. Dev. & 33.72 & 423.27 & 5.41 & 10.49 \\
\hline Observations & 52 & 52 & 52 & 52
\end{tabular}

Other descriptive tests namely kurtosis and skewness were conducted to validate the goodness of fit of the model. Skewness gauges symmetry while Kurtosis is best for calculating the peaked-ness of the distribution. Drawing from the Jarque-Bera test, the dependent variable return on equity (ROE) was observed to be normally distributed given that its probability at 0.00 is less than 0.05 . The variables' right tail was longer than the left reflecting that an investor is likely to expect large returns. The independent variable, debt to equity ratio, DER, was normally distributed but showed negative skewness and extremely high kurtosis because adoption of debt by an airline indeed results to strained returns and high risk for any investor. ATO, Asset turnover variable was also normally distributed with heavy tails and showed moderate skewness of 0.95 which ranges between 0.5 and 1. The remaining independent variables $\mathrm{CR}$ showed moderate skewness but was not normally distributed since its probability 0.17 was greater than 0.05 .

In summary, the descriptive statistics showed that the two out of three independent variables: current ratio (CR), and asset turnover (ATO)- had means that were remarkably reliable, had normal to moderately skewedness but were not normally distributed. By contrast, the last independent variable the debt to equity (DER) ratio, had unreliable mean values spread over a large range, appeared negatively skewed but was normally distributed. The dependent variable, Return on Equity (ROE) was also normally distributed as evidenced by Jarque-Bera statistic. It appeared to be huge negative correlation to increases in debt-to-equity ratio and a minimally negative effect from increases in current ratio. There was little to no correlation effect observed on and asset tangibility for the sampled airlines.

\section{B. Diagnostic Tests Results for Correlation}

Diagnostic test results ensure that study results are valid, more robust and ensure that study results are in tandem with the requirements of the multiple regression technique employed in the study (Shim, Shakawi, \& Azizan, 2017).

Table IV: Correlation of ROE with Independent Variables

\begin{tabular}{ll}
\hline & ROE \\
\hline DER & -0.7131 \\
CR & -0.0237 \\
ATO & -0.03422 \\
\hline
\end{tabular}

Notation
ROE- Return on Equity
DER- Debt to Equity Ratio
CR- Current Ratio
ATO- Asset Turnover

From the table above DER had a strong negative correlation with ROE from established by its coefficient of 0.71. The coefficients of CR and ATO showed little to no correlation with ROE based on coefficients of -0.02 and -0.03 
respectively. This means that over the 13 year period, the return on equity for the four African Flag carriers was negatively affected by increases in leverage but remained unaffected by any increases or decreases in liquidity and asset tangibility. Given that the correlations are below 0.8 , the results indicate that there is no multicollinearity.

\section{Panel Unit Root Test}

Testing for stationarity is widely employed when a researcher has time series data. This involves checking whether the statistical properties namely variance mean, and autocorrelation of a variable does not change over time. Particularly, the data series itself may change but the way it changes i.e., has a constant slope over time is expected to remain constant. This property can therefore be handy in applied research when running analysis and statistical tests such as trend estimation, causal inference, and forecasting. A time series is considered non-stationary if it contains a unit root, but the converse is not true. Non-stationarity is caused by the process of periodic autoregressions. This main feature yields useful narrations as autoregressive parameters can vary with every season (Boswijk et al., 1997). Occasionally a time series may have more than one unit root in which case it is required to transform the series into a stationary series. Testing for unit roots is commonly done using the Augmented
Dickey Fuller (ADF) unit root test. Nevertheless, over the last two decades, it has become common practice to use Levin, Lin and Chu for common unit root process while individual unit process may use Im, Pesaran and Shin panel unit root test, Phillips-Perron-Fischer Chi Square panel unit root test and ADF-Fischer chi square test. In this evaluation, multiple unit roots were the most desirable due to the unbalanced nature of the panel data. Moreover, using pooled panel data comes with an assumption of cross-sectional independence and inter cross-sectional homogeneity.

From the table $\mathrm{V}$ below, the p-value is displayed below each statistic and $* *$ and $*$ indicate rejection of null hypothesis at $1 \%$ and $5 \%$ significance, respectively. All panel unit root tests have null hypothesis tests of nonstationary financial risk. Two variables, ROE and CR had consistent results across all four tests. The probability of Levin, Lin, and Chu statistic for Return on Equity (ROE), Debt to Equity Ratio (DER) and Asset Turnover (ATO) variables each have a value less than 0.01 which is significant at the $1 \%$ level of significance. The test rejects the null hypothesis of the presence of a unit root and demonstrates that the variables are stationary and have no unit root. The same test failed to reject the null for Current Ratio (CR) and the variable was observed to have a unit root.

\section{Table V: Unit Root Test}

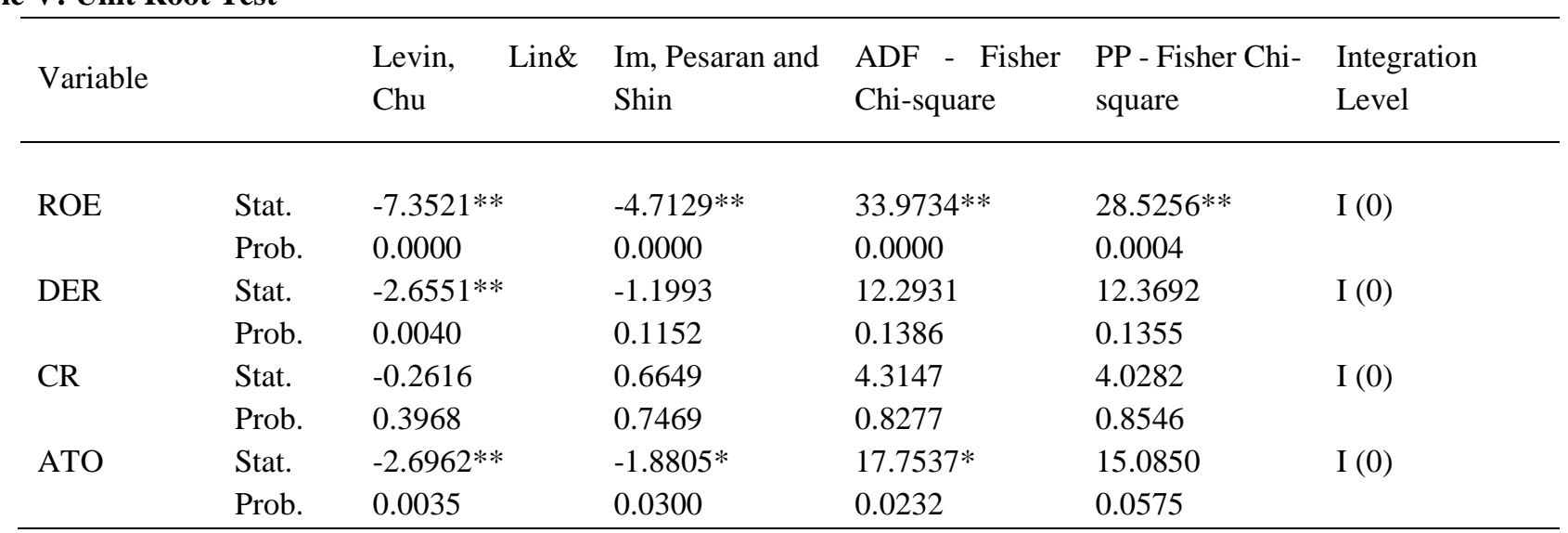

$$
\begin{array}{ll}
\text { Notation: } & * \text { significant at } 5 \% \text { level } \\
& * * \text { significant at } 1 \% \text { level }
\end{array}
$$

The three other tests implemented namely Im, Pesaran and Shin unit root test, Augmented Dickie-Fuller ADF-Fisher Chi-square, and Phillips-Perron Fisher Chi square, confirmed stationarity for return on equity and failed to reject the null for debt-to-equity ratio and current ratio at both the $1 \%$ and $5 \%$ significant levels. Furthermore, the three tests gave mixed results for the asset turnover variable, Philips-Perron Fisher Chi Square test confirmed the presence of a unit root, yet the other two tests confirmed stationarity at the 5\% level. All tests failed to reject the null at the $1 \%$ significance level and showed the presence of unit root for DER, CR and ATO. As a result, first difference treatment was applied on this research evaluation as portrayed in table VI below. All four tests unanimously reject the null of unit root proving that all variables are stationary after the first difference. 
Table VI: Unit Root Tests for First Difference

\begin{tabular}{|c|c|c|c|c|c|c|c|}
\hline Variable & & $\begin{array}{l}\text { Levin, } \\
\text { Chu }\end{array}$ & Lin\& & $\begin{array}{l}\text { Im, Pesaran and } \\
\text { Shin }\end{array}$ & $\begin{array}{l}\mathrm{ADF} \text { - Fisher } \\
\text { Chi-square }\end{array}$ & $\begin{array}{l}\text { PP - Fisher Chi- } \\
\text { square }\end{array}$ & $\begin{array}{l}\text { Integration } \\
\text { Level }\end{array}$ \\
\hline \multirow[t]{2}{*}{ DROE } & Stat. & $-7.3035^{* *}$ & & $-5.2205 * *$ & $37.5249 * *$ & $70.0739 * *$ & I (1) \\
\hline & Prob. & 0.0000 & & 0.0000 & 0.0000 & 0.0000 & \\
\hline \multirow[t]{2}{*}{ DDER } & Stat. & $-6.5678 * *$ & & $-4.5936 * *$ & $32.7718 * *$ & $64.9344 * *$ & I (1) \\
\hline & Prob. & 0.0000 & & 0.0000 & 0.0001 & 0.0000 & \\
\hline \multirow[t]{2}{*}{ DCR } & Stat. & $-6.4377 * *$ & & $-4.0560 * *$ & $29.2799 * *$ & $28.2066^{* *}$ & I (1) \\
\hline & Prob. & 0.0000 & & 0.0000 & 0.0003 & 0.0004 & \\
\hline \multirow[t]{2}{*}{ DATO } & Stat. & $-7.1202 * *$ & & $-4.7737 * *$ & $33.5844 * *$ & $39.8697 * *$ & I (1) \\
\hline & Prob. & 0.0000 & & 0.0000 & 0.0000 & 0.0000 & \\
\hline
\end{tabular}

Notation: ** significant at $1 \%$ level

D - First difference

\section{Panel Hausman Test for Financial Structure Elements}

According to Musiega, Olweny, Mukanzi and Mutua (2017), a Hausman test is used to determine whether to use the random effects model or the fixed effects model to address the study objectives. In the table VII below, the Hausman test is distributed as chi-square statistic with 6 degrees of freedom. The probability for return on equity at 0.1653 was greater than 0.05 . This provides little evidence against the null hypothesis that the random effect model is appropriate.
Table VII: Correlated Random Effects - Hausman Test

\begin{tabular}{ll}
\hline & ROE \\
\hline Chi-square statistic & 5.0909 \\
Prob. & 0.1653 \\
\hline
\end{tabular}

Drawing from the Hausman test, the researcher concluded that the random effect model was most appropriate and thus adopted it to scrutinize the casual effect of financial structure elements on firm performance of flag carriers in Africa.

\section{E. Financial Performance and Leverage}

The null hypothesis $\mathrm{H}_{01}$ : Leverage has no significant influence on financial performance of flag carriers in Africa

Table VIII: Regression of ROE on Leverage Measures

Dependent Variable: ROE

Method: Panel EGLS (Cross-section random effects)

\begin{tabular}{lllll}
\hline \hline Variable & Coefficient & Std. Error & t-Statistic & Prob. \\
\hline \hline C & 0.325458 & 0.141915 & 2.293334 & 0.0261 \\
DER & -0.208741 & 0.027716 & -7.531424 & 0.0000 \\
\hline \hline & Weighted Statistics & \\
\hline \hline R-squared & 0.534321 & Mean dependent var & 0.095933 \\
Adjusted R-squared & 0.525008 & S.D. dependent var & 0.790410 \\
S.E. of regression & 0.544748 & Sum squared resid & 14.83753 \\
F-statistic & 57.37016 & Durbin-Watson stat & 2.328883 \\
Prob(F-statistic) & 0.000000 & & \\
\hline \hline & Unweighted Statistics & \\
\hline \hline R-squared & 0.507839 & Mean dependent var & \\
Sum squared resid & 16.59732 & Durbin-Watson stat & 2.092440 \\
\hline \hline
\end{tabular}


As regards to the relationship between the leverage proxy and Return on Equity ROE, the study showed Debt to Equity Ratio (DER) has a significant relationship with ROE because the partial regression coefficient of -0.208741 had a p-value of 0.0000 which is less than $1 \%$.

Planes are the primary assets that generate the lion's share of an airline's revenue thus it can be seen that when African flag carriers take on more debt to purchase new planes or re-furbish existing ones, they are not able to sufficiently generate incremental revenue. This significant negative effect of leverage on financial performance is consistent with a study conducted on 15 non-financial firms listed on the Ghana Stock Exchange over the period 20082017 by (Musah \& Kong, 2019) wherein a significantly negative association between leverage and the firms' financial performance measured by Return on Assets, ROA was observed. Using secondary panel data, the study assessed the bivariate association between leverage and firm's performance by employing the Pearson Product-Moment Correlation Coefficient technique.

From table VIII above, the regression results of Return on Equity ROE with leverage metrics appropriate that the model is significant at $1 \%$ level as the F-stat probability value was less than 0.01. The Durbin- Watson value was 2.328883 showed there is no serial correlation in the model while the $\mathrm{R}$-squared indicates that leverage ratios only explain $53.43 \%$ of performance of return on equity. It can be inferred from the above results above for Debt to Equity that this study rejects the null hypothesis that leverage has no significant influence on financial performance of flag carriers in Africa.

\section{F. Financial Performance and Liquidity}

The null hypothesis $\mathrm{H}_{02}$ : Liquidity has no significant influence on financial performance of flag carriers in Africa.

Table IX: Regression of ROE on Liquidity Measures

Dependent Variable: ROE

Method: Panel EGLS (Cross-section random effects)

\begin{tabular}{lllll}
\hline \hline Variable & Coefficient & Std. Error & t-Statistic & Prob. \\
\hline \hline C & 0.273671 & 0.349422 & 0.783211 & 0.4372 \\
CR & -0.115456 & 0.375895 & -0.307151 & 0.7600 \\
\hline \hline
\end{tabular}

\begin{tabular}{llll}
\hline \hline \multicolumn{4}{l}{ Weighted Statistics } \\
\hline \hline R-squared & 0.001912 & Mean dependent var & 0.128870 \\
Adjusted R-squared & -0.018050 & S.D. dependent var & 0.798041 \\
S.E. of regression & 0.805211 & Sum squared resid & 32.41821 \\
F-statistic & 0.095769 & Durbin-Watson stat & 2.177523 \\
Prob(F-statistic) & 0.758254 & & \\
\hline \hline & Unweighted Statistics & 0.177473 \\
\hline \hline R-squared & 0.000051 & Mean dependent var & 2.092119 \\
Sum squared resid & 33.72164 & Durbin-Watson stat & \\
\hline \hline
\end{tabular}

A look at the t-statistics shown in Table 4.7 above reveals that the coefficient for Current Ratio, CR is not significant at the $5 \%$ or $1 \%$ level based on its p-value of 0.076. The F-statistic of the model, 0.095769 was insignificant at the $1 \%$ level based on its $\mathrm{p}$ value of 0.758254 $(>1 \%)$. The liquidity proxies could only explain $1.91 \%$ of the variance in performance of ROE as indicated by R-squared value. No serial correlation was evidenced in the model as established by the Durbin Watson value at 2.177523 . It can be concluded that this study fails to reject the null hypothesis that liquidity has no significant influence on financial performance of flag carriers in Africa.

\section{G. Financial Performance and Asset Tangibility}

The null hypothesis $\mathrm{H}_{03}$ : Asset tangibility has no significant influence on financial performance of flag carriers in Africa.

The results presented in the table below indicate that an increase in asset tangibility, measured in terms of Asset Turnover, ATO ratio, by one percent will result into a 0.055465 per cent decline in ROE all else held constant. The $\mathrm{t}$-statistic of the coefficients for asset tangibility is not significant at the $5 \%$ level when explaining performance of Return on Equity for the sampled African flag carriers. 
Table X: Regression of ROE on Asset tangibility Measures

Dependent Variable: ROE

Method: Panel EGLS (Cross-section random effects)

\begin{tabular}{lllll}
\hline \hline Variable & Coefficient & Std. Error & t-Statistic & Prob. \\
\hline \hline C & 0.243050 & 0.363325 & 0.668962 & 0.5066 \\
ATO & -0.055465 & 0.276675 & -0.200470 & 0.8419 \\
\hline \hline
\end{tabular}

Weighted Statistics

\begin{tabular}{llll}
\hline \hline R-squared & 0.000819 & Mean dependent var & 0.126580 \\
Adjusted R-squared & -0.019164 & S.D. dependent var & 0.797440 \\
S.E. of regression & 0.805045 & Sum squared resid & 32.40489 \\
F-statistic & 0.041005 & Durbin-Watson stat & 2.156865 \\
Prob(F-statistic) & 0.840350 & & \\
\hline \hline & Unweighted Statistics & \\
\hline \hline R-squared & 0.001160 & Mean dependent var & 0.177473 \\
Sum squared resid & 33.68425 & Durbin-Watson stat & 2.074059 \\
\hline \hline
\end{tabular}

The F-statistic of the model, 0.041005 was also insignificant at the $1 \%$ level based on its $p$ value of 0.840350 $(>1 \%)$. The low R- Squared value indicated that the asset tangibility metrics did not explain any of the variance in performance of ROE. Lastly, the results showed there was no serial correlation detected in the model based on the Durbin Watson value at 2.156865 . It can therefore be inferred that this study fails to reject the null hypothesis that asset tangibility has no significant influence on financial performance of flag carriers in Africa.

Like the liquidity metric, the asset tangibility proxies also revealed non-existent explanatory power based on the R-squared value of $0-1 \%$ with no serial correlation was detected. This implied that both values were not likely to change in future time periods in a manner akin to the past periods.

\section{CONCLUSION}

The quest for examining the relationship between financial structure and financial performance has always been considered as vital among academics and finance managers across various industries. In particular, the airline industry has remained an area of intrigue as one of the few to have consistently low profitability and low returns on capital which has mostly been attributed to the asset-heavy nature of the industry with high fixed cost relating to fuel, labour and maintenance, the intensity in competition, systemic challenges in doing business and overall macroeconomic environment.

\section{Leverage and its influence on Performance}

The first objective was to establish the effect of leverage on firm profitability performance of flag carriers in Africa. The results revealed there was no multi-collinearity for leverage indicators proxied by Debt-to-Equity Ratio (DER). The findings from the panel regression showed that DER was seen to have a significant effect on profitability metrics of flag carriers in Africa. The DER ratios for the sampled airlines, was observed to be normally distributed with an average airline approximately within three standard deviations from the mean. The leverage metrics exhibited an R-squared of $53 \%$ on ROE. The key feature distinguishing ROE from other returns measures, namely ROA, is debt. If a firm has no debt, then ROA would equal ROE, all other things held constant. It follows therefore that if a firm adopts financial leverage, then ROE would see an upswing compared to ROA given that equity is derived from the difference between assets and total debt. The increase in debt would have an inverse effect in equity, decreasing the denominator value in the ROE equation and effectively boosting the ROE. In parallel, the heightened debt level results also increase total assets which amplifies the denominator of the ROA equation and decreases its ratio. Based on the above, one can thus conclude that these findings suggest that firms in the airline sectors should finance their operations with debt thus agreeing with Modigliani and Miller (1963) capital relevance theory.

This study has demonstrated that leverage is a quintessential indicator of profit volatility particularly in the airline industry. The results of the panel regression concluded that this relationship can be negative when debt is financed 


\section{"Relationship between Financial Structure and Financial Performance of Flag Carriers in Africa"}

by equity. To ensure profitability, airline managers should therefore ensure they make prudent choices whenever acquiring any debt obligations and source for capital injections that have the least effect on profitability of the airline firm. Any investment by airlines is necessitated by internal desire to offer customers more choices by optimizing services to existing routes and opening additional destinations, all decisions that require substantial fleet investment and capacity right sizing. Moreover, intense competition amongst themselves and with non-African carriers who have deployed newer, fancier aircrafts with multiple frequencies out of key hubs such as Nairobi and Johannesburg has compounded the desire to aggressively expand the hub infrastructure in order to meet local and global demand as the airlines grapple with remaining relevant out of and into their home markets.

Being a heavily leveraged industry with high costs in aircrafts, spare parts as well as maintenance, African flag carriers that have chosen to finance these costs through equity are not adequately rewarded. As a result, the typical airline's balance sheet is plagued with high debt burdens and low operating revenue that is not nearly enough to cover the high fixed and structural costs. Airline mangers are therefore under intense pressure to both generate additional revenue and make structural changes to their business and overheads without affecting the flexibility of operations. Since Africa flag carriers are mostly owned by governments, achieving this duality has often been an uphill battle as governments impose stringent demands in exchange for any investment rendered. Some of which may be commercially unprofitable and only serve political interests. To avert this conundrum, some of the flag carriers have opted to generate funds from issuance of equity, termed by pecking order theory as the costliest source of capital. In addition to using owned aircrafts and other assets to acquire debt, an airline can secure apposite financing by issuing high-yield corporate bonds. In recent times, another innovative solution adopted by American carriers to secure finances and improve liquidity involved using their loyalty programs as collateral. This entailed selling airline miles to the bank which the bank uses to attract and reward high net-worth customers when they obtain or use their credit cards. In March 2021, American Airlines raised a total of \$10 Billion on bonds and loan offering collateralized by their American Advantage loyalty program as collateral. Delta Airlines raised \$9 Billion from with borrowings backed by its SkyMiles program in September 2020 while United airlines managed to scoop \$6.8Billion using its Mileage Plus Program in June of the same year.

IATA 2016 annual report notes that the return of investment in airlines globally had seen significant rise but airlines in Africa have not seen this similar growth results. The empirical results in this study reveal that there could be gap on financing needs. An airline's choice in financing needs between debt and equity is often influenced by its ownership structure. Airlines that are wholly government owned have access to comparatively cheaper sources of capital than those seeking public and private investments.

\section{Liquidity and its influence on Performance}

The second objective was to establish the effect of liquidity on firm profitability performance of flag carriers in Africa. The results divulged that regression model of the panel data for liquidity measures proxied by Current Ratio (CR) was insignificant when regressed on Return on Equity (ROE). R-squared value showed that liquidity metrics did not explain the performance of ROE. The findings in this research contradicted the study on pharmaceutical companies listed on Bombay Stock exchange over a 10year period ranging between 2018 to 2017 (Yameen et al., 2019) which concluded that a significant relationship existed between current ratio and quick ratio on profitability measured by return on assets. Liquidity in an airline context refers to managing cash balances and minimizing cash burn. Current ratio is a good measure of short-term liquidity by assessing whether a company can pay off all its short-term liabilities using all its current assets. An alternative measure such as quick ratio is a more conservative measure that can be used to explain if an airline can cover short term obligations with its assets which are easier to liquidate. The ratios are especially useful in highly- levered industries due to the remarkable amount of debt.

Cash collected from ticketed revenues can be invested in short- term interest bearing investments or sometimes airline treasurers will be safeguarded in a bank pending payment of fuel, crew and other business expenses. In periods of excessive cash, airlines have also been observed to hold cash in anticipation of cyclical downturns and emergency cases. Airline seats which are the bulk of inventory and are a highly perishable asset. It is therefore critical that airline managers ensure these are turned into revenue quickly and efficiently in order to avoid any revenue spoilage or spillage. To this end, airlines typically employ systems to handle the dynamic and complex nature of inventory management. This ensures the right inventory is availed at the right price, at the right time to the right customer else if a flight leaves with empty seats or it departs with many occupied seats that were sold below optimal value, that revenue foregone can never be recovered.

Traditionally, airlines have used bank revolving credit facilities and have accessed short term loans and grants from governments to supplement any seasonal revenue shortages in order to meet their obligations relating to working capital commitments. Also, by extending invoice payments periods to suppliers, airlines also achieve competitive credit terms and reduce the cash conversion cycles. Should airlines fail to maintain adequate working capital, they may require additional long-term borrowing which comes with increased interest expenses. In conclusion, a proper liquidity management strategy implies the airline can continue to generate income from its existing assets and 


\section{"Relationship between Financial Structure and Financial Performance of Flag Carriers in Africa"}

therefore influence the return on assets. It can be concluded therefore that if the macro-economic environment is conducive, airline firms can increase their profitability without affecting their liquidity and vice versa.

The regression results showed that the liquidity measures was insignificant when regressed on Return on Equity (ROE). In hindsight, the years leading up to 2019 were generally the most profitable in the airline industry yet African flag carries still wrestled with challenges in capital adequacy. The emergence of a global pandemic which has been particularly devastating to the airline industry, has only exasperated the importance of having cash reserves and liquid assets. As the pandemic set in and demand for passenger travel dropped to unprecedented levels, borders were shut across the world and airlines were forced to ground majority of their aircraft for months.

Airline managers creatively responded by converting some passenger aircraft into cargo planes in a response to the shifting demand. While this was a commendable effort on their part, majority of airline revenues arise from passenger revenue. In fact, large airlines typically carry more cargo in the belly of passenger aircrafts than on cargo flights. To minimize current liabilities, airlines enacted leaner human cost structures using forced use of leave balances, furlough, retrenchment, pay cuts and bonus suspensions. In the same breath, supplier payments were prioritized with extensions required and deferred payment plans negotiated. Whereas all these short-term solutions are not nearly enough to salvage the damage arising from the high levels of cash burn and subsequent losses that airlines reported, they have been strategic in ensuring continued operations at minimal cost level and reduced the profitability gap.

Pre-covid, when an airline grappled with liquidity and solvency issues, one of the quick and viable tactics employed was the sale of airport slots. Slots are controlled by local civil aviation authorities and slot control rules can vary between regions or even seasons. The regulators usually require airlines to maintain at least $80 \%$ utilization rate of a slot pair per year. In some key airports around the globe, where demand is high and airport capacity is constrained, the slots are very scarce and highly valuable therefore they can be a good source of immediate cash injection. In 2016, Kenya Airways sold its morning arrival slot in London Heathrow to Oman Air for a record-breaking \$75 Million. In the previous year, SAS Scandinavia sold a pair of slots to American Airlines and received $\$ 60$ Million, then two years later sold another pair for $\$ 75 \mathrm{Million}$. In current times, slot control rules have been temporarily relaxed or suspended in various airports across the world. While slot sales are not a perpetual means of enhancing liquidity, they still provide airlines with an innovative way of raising funds outside acquisition of debt and equity injections from shareholders.

\section{Asset Tangibility and its influence on Performance}

The last objective was to determine the effect of asset tangibility on firm profitability of flag carriers in Africa. The panel data regression results disclosed that the correlation values for asset tangibility barometers proxied by Asset Turnover (ATO) were within acceptable range to conclude that there was no autocorrelation present in the model. While the findings from the panel regression showed the asset tangibility barometer was not significant to the performance ratio, it did reveal that the relationship was a negatively insignificant relationship with respect to Return on Equity (ROE) of flag carriers in Africa. This conclusion supports the findings of (Mwaniki \& Omagwa, 2017) who posited that the extent with which tangible assets are either negatively or positively associated with debt is not clear.

Intrinsically, an airline firm's balance sheet comprises a higher stake in fixed assets than current assets. Purchasing an aircraft is not a simple or straightforward process, instead it involves a series of complex, multifarious procedures. Airline managers commence with a profound analysis of the airlines future which involve identifying markets with potential to handle increases in capacity either in terms of frequency or size of aircraft, expansion to new markets and overall efficiency of current aircraft against newer more efficient ones. Based on this information, a guestimate will be done on the foremost types of aircraft to suit and service the above needs while in parallel considering the existing aircraft types and configuration the airline already has in order to maximize efficiency in terms of maintenance and pilot/crew requirements. The entire process involves a lot of research and engagement with senior management, aviation brokers, an aircraft financing company and an aviation attorney. An order will be made years in advance and the aircraft is pre-purchased usually in USD exposing the airline to foreign currency risk. These purchase terms are usually complex and involve significant deposits and progress payments, purchase rights, inclusion of options such as the right to delay delivery and manufacturers credit such as spare parts, training, or marketing support. All the costs relating to bringing the aircraft into working condition will be capitalized in the balance sheet less the manufacturer's discounts. After purchase, any modification of an airline assets for example spare parts, rotables (parts which are maintained and reused), repairables (parts that can be repaired and reused for a limited period), in-flight entertainment and cabin refurbishment are only capitalized if they are deemed to have probable future benefits at the shorter of the useful life of the asset and the remaining life of the aircraft.

Although an airline's assets are costly, long lasting and their management in an airline's balance sheet is multifaceted they generate the bulk of the airline's revenue. If sales are profitable then return on assets would be seen to improve and the airline firm generates additional returns per every dollar invested. Ergo, for a capital-intensive industry, a 


\section{"Relationship between Financial Structure and Financial Performance of Flag Carriers in Africa"}

smaller ROA has a substantial meaning on profits due to the magnitude of assets required to be in business. Du Point Analysis simplifies ROE as the product of operating efficiency, financial leverage, and asset use efficiency. It is a useful tool for analysts when investigating changes in ROE and comparing performance between two airlines to determine if profitability is being driven by using debt or an airlines efficient use of its assets. In any case, it remains difficult to establish the direct impact of asset tangibility to profitability in the African flag carriers, but one can investigate if an airline utilizes its assets more efficiently over time or in comparison to its peers.

In this empirical study, asset tangibility was observed to have an insignificant effect on financial performance in African airlines. The researcher contends that asset tangibility does however hold a somewhat significant relationship with profitability outside Africa. In the airline industry, a key and popular avenue for achieving short term liquidity involves sale \& lease-back of aircraft and engines parts or any other tangible assets. These transactions are highly effective and sought after for unlocking additional cash while allowing the airline continued use of the asset. (Aircraft Sale and Leaseback During COVID-19 | ACC Aviation, n.d.). In America, Delta Airlines is reported to have secured \$1 Billion while easyJet from Europe unlocked \$266 Million in August 2020 from sale and leaseback transactions. Of noteworthy importance is that easyJet has garnered a total of \$804 Million from these transactions. Earlier in the year, in March 2020, in Asia, Cathay Pacific managed to latch \$704 Million after selling six Boeing 777-300ER aircraft whileIII. most recently in March 2021, Singapore managed to unlock $\$ 1.5$ Billion from 11 aircraft. Older aircraft with attractive current market values fetch larger cashbacks as loan amortization rates surpass the decline in aircraft value. A huge concern with these transactions is obviously their tendency to favor companies with healthy balance sheets and their reliance on market value. Regardless, by engaging in these deals, an airline firm could effectively remove the debt associated with older aircraft off its balance sheet and thereby appear more profitable in the short term. Data from (Covid19's Impact On Sale And Leaseback Activity, n.d.) ) shows that no African airlines appear to have engaged in leaseback transactions in Q3 2020 while their counterparts in America, Europe and Asia witnessed several transactions and Middle East Carriers were reported to have only two transactions. This proved that in that dire period transactions were centered around buyers with access to low-cost immediate funding that had strong financial backing and that African airlines were possibly struggling to obtain parallel access.

It is note noteworthy that under the new IASB and FASB regulation effective in 2019, airlines will be required to include operating lease obligations in their balance sheet. These will see an increase in current liabilities reported by airlines and subsequently a reduction of liquidity as measured by liquidity ratios. In the periods under consideration by this study, lease payments were accounted for in the income statements as operating expenses.

At the time of completing this paper, two of the flag carriers considered in this study are under liquidation having been unable to re-start operations post border re-opening due to abyssal financial problems and inability to secure adequate support. The other two have received some financial support from their local governments but are still neck-deep in the losses as costs continue accruing from aircraft lease payments, aircraft maintenance, staff salaries and loan repayments. Specifically, part of the ongoing investigations in South African Airways are tied to irregular sale and lease back transactions which resulted in billions of unappropriated funds in 2012. Contrastingly, Ethiopian Airlines, the largest pan-African airline entered a MOU with a leasing company in 2014 where it garnered support for its 15-year fleet expansion strategic plan that included support provisions in sale \& lease back on top of access to commercial loans and favourable lease options. In 2018, Kenya Airways engaged in Sale and lease back of 6 aircraft and a spare engine and more recently was reported to be in talks with lessors to return leased aircraft early. In the same year, Air Mauritius also tendered a bid for one aircraft with accompanying engine parts and in 2019, Air Mauritius put up five aircraft for sale after entering administration. This scholar thus concludes that African carriers require more than just financial support not only to endure the crisis but also to reach levels of sustainable profitability.

\section{RECOMMENDATION}

Although African governments recognize the critical role that aviation contributes to the overall economy, the researcher recommends that fiscal resources be directed to restructuring and sustainability of their national carriers as a matter of priority or in line with other government priorities.

The repercussions for lack of access to cheap and adequate funding are graver for airline firms in comparison to other industries. Besides that, the source of funding must be sufficient to cover long maturity periods with options to refinance when critical shocks hit the economy which has been hypothesized as every seven years. Lenders are typically averse to all these stringent conditions at the same time and would typically need to offset their assumed risk against higher premiums or shortened periods. Governments could consider proactively reaching out to the lenders and offering prudent support in the form of tax rebates and refunds to substitute the deficit provided that such a deficit arose out of a direct support to a flag carrier. Not only would this motivate lending institutions to offer financial support, but also the support would be offered at a competitive basis and from multiple sources. With the financial flexibility equation resolved, a typical flag carrier would then be able to expand its route network and compete effectively when strategic routes are threatened by more competitors thereby increasing and protecting its passenger revenue streams and 


\section{"Relationship between Financial Structure and Financial Performance of Flag Carriers in Africa"}

subsequently allowing enough cash generation to pay off assumed debt. Without this reassurance, airline managers have no option but to result in grounding of aircraft and steep capacity cuts. The solutions may appear sensible in the short term but have long lasting negative effects on passenger revenues. First, consumer confidence will be shattered by the airlines inability to provide a consistent schedule or options. Imagine a typical businessman who frequently travels for meetings between a short distance say Nairobi to Dar es Salam where on a given day there were five daily flights that have now been reduced to two. With two daily flights, the optimal capacity allocation is to have one morning and one evening departure. That being the case, the businessman who would have previously been able to attend a one or two-hour meeting in the morning and return to his origin by lunchtime would be forced to stay in his destination for a whole day just to travel back on the same carrier or worse, forced to board a competitor airline that may involve additional time spent on transit. With a poor product offering, the airline becomes less and less competitive and risk current and future revenue opportunity. Secondly and perhaps most critical is that reduced flying means an airline does not attain optimal aircraft utilization and crew optimization, yet the cost structure remains unchanged if not higher. For example, an airline company may be required to park an airplane for a whole day in a foreign station just to achieve minimum crew rest times and to connect it to the rest of its network upon returning to the hub. In this situation of diminished revenues and increased costs, paying debt burdens becomes even more strenuous and inevitably the airline will collapse should adequate financial support not be rendered.

In addition to using fiscal resources to support a national carrier's ability to generate sustainable income, this research also contends that policies must be enforced to adequately manage the inevitably high fixed costs. The duality of fiscal resources and cost management must not be mutually exclusive so as to put African airlines in a better position to be able to compete effectively against other international carriers such as those in Europe or Middle East.

To ensure all stakeholders are invested, a tri-partite debt covenant would have to be ratified between the airline, government, and local lenders. Historically, debt covenants have favoured the resolution of agency problems and ensured interests in all parties are aligned without placing unnecessary burdens on the borrower. On the lenders part, they would offer secured and unsecured credit facilities with favourable debt schedules to support African flag carriers' fleet operational and expansion plans, including but not limited to operating \& finance lease, sale and lease back and commercial loans. Additionally, under the same umbrella, they should also choose to extend these financial backing to aircraft lessors of African carriers, regardless of whether an airline owns a certain percentage or all its aircraft or equipment that would be considered critical to sustain operations. Practically though, lenders would in return require airlines to meet and maintain some key financial metrics such as minimum asset coverage ratios, minimum fixed coverage ratios, minimum debt to equity ratio, among others. They may also opt to include provisions where any asset sales proceeds are used for debt reduction and not to enhance liquidity for general purposes. Both bankers and airlines may also appeal to the government for tax savings from debt.

On its part, government support could be achieved in a myriad of ways. At the outset, periodic equity injections should be granted to the airline and short-term provisions could be made to grant flag carriers and their lenders tax holidays for a limited period. In the long run, the governments should look to sell their shareholding and reduce limitations involved with government influences and political interference. Policies relating to agent distributions can be implemented that require local agents to be taxed lower when they sell the national carrier with a directive to maintain a minimum sales percentage level on the flag carriers, local airlines, or African airlines. Secondly, government should enforce aviation union bodies and airlines to adopt strategies that support the airline profitability in addition to emphasizing the protection of jobs and livelihood. Minimum supply of labour, adequate working conditions and reasonable renumeration levels should be well negotiated and guaranteed by government, employer and the union. Thirdly, government employees, civil servants and persons conducting any business using government grants should only be re-imbursed for travel on the national carrier or on flights that are code-shared with a local African carrier for all travel types including leisure travel. In instances where the flag carrier does not serve a destination, government employees, civil servants and agents must travel on the African Flag carrier as far as possible. Additional flight costs should not be used as justification to fly on foreign carriers. This specific practice is phenomenally successful in America and ensures all American carriers receive some sustainable levels of income from the high-yielding government travel. Airlines are required to bid for routes in advance of a financial year to allow the government to scrutinize the best rates and ensure equitable distribution amongst all carriers. If local African governments adapted this practice with their flag carriers and extended it to other African flag carriers or African-owned airlines, the overall aviation industry would be boosted to greater heights. Another key policy review from the government should involve seeking more liberalization in existing Air Service Agreements (ASAs) and signing new ASAs where they do not exist especially in key trade and tourism markets.

Lastly, as part of the covenant, an airline would commit to search for experienced executives with proven success records to provide steadfast leadership. A reasonable percentage of these executives should be qualified local individuals or of African descent with similar renumeration profiles. Foreign employee salary and allowances should be 
justifiable and in line with other industry standards. These airline mangers would have to commit to a long-term business plan outlining commercial activity they plan to undertake in order to achieve sustainable profitability. It should also define how they intend implement or maintain service excellence in a cost-efficient manner and include a provision to upskill the existing local workforce to ensure business continuity. A periodic review of this business plan would be done in conjunction with the selected representatives of the lenders and government to ensure it remains feasible. External auditors should be utilized every quarter to audit all financial transactions especially those regarding procurement and supply of goods and services. Any fraudulent transactions should be investigated and prosecuted according to the full extent of the applicable local laws. Periodic equity injections should only be submitted by the government upon satisfactory audit results and maintenance of financial ratios described above. Further, a chunk of the top executives, mid-level management and pilot renumeration should be causally linked to performance measures that are qualifiable and quantifiable and paid in equity that cannot be sold or transferred for a significant time period and which is forfeited if an employee voluntarily leaves service within that period.

With minimized funding gaps, and favourable policies in enforcement, competent airline professionals should be able to implement day-to-day initiatives and actions that achieve the desired levels of success. All in all, airline managers should be shrewd enough to negotiate beneficial terms ranked to their individual needs and areas of concern with bankers, lessors, and the government with the overall goal of ensuring sustained profitability while remaining conscious of their ability to adhere to their commitments and avoid unnecessary breaches.

This study has touched on key financial elements affecting profitability with an in-depth review on each element. The researcher recommends a further review on how profitability levels have been impacted by sale and leaseback activities of carriers in Africa compared to their counterparts in Europe and America. Finally, future scholars would also be keen to study non-financial structure metrics commonly used in the airline industry such as available seat kilometres (ASK), Revenue per available seat Kilometre (RASK), Cost per available seat Kilometre (CASK), Passenger Load Factors and Yield to examine how efficiently African airlines have been managed and to understand the varying performance between airlines in similar regions.

\section{REFERENCES}

1. Abeywardhana, D. K. Y. (2017). Capital Structure Theory: An Overview. Accounting and Finance Research, 6(1), 133-138.

2. Abubakar, A. (2017). Financial Leverage a nd Firms ' Performanc e : A Study of Quoted Companies in the Nigerian Stock Exchange (pp. 1-31).
3. Adom, D., Hussein, E. K., \& Agyem, J. A. (2018). Theoretical and Conceptual Framework: Mandatory Ingredients of Quality Research. International Journal of Scientific Research, 7(1), 438-441.

4. Ahmed, F., Awais, I., \& Kashif, M. (2018). Financial Leverage and Firms' Performance: Empirical Evidence from KSE-100 Index. Etikonomi: Jurnal Ekonomi, 17(1), 45-56.

5. Aircraft Sale and Leaseback During COVID-19 | ACC Aviation. (n.d.). Retrieved May 17, 2021, from https://www.accaviation.com/aircraft-sale-andleaseback-during-covid-19/

6. Al-Qadi, N. S., \& Khanji, I. M. (2018). Relationship Between Liquidity and Profitability: An Empirical Study of Trade Service Sector in Jordan. Research Journal of Finance and Accounting, 9(7), 153-157.

7. Albers, M. J. (2017). Quantitative Data Analysis In the Graduate Curriculum. Journal of Technical Writing and Communication, 47(2), 215-233. https://doi.org/10.1177/0047281617692067

8. Alzharani, A. M., Che-ahmad, A., \& Aljaaidi, K. S. (2012). Factors Associated with Firm Performance: Empirical Evidence from the Kingdom of Saudi Arabia. Accounting \&Taxation, 4(2), 49-56.

9. Anake, A. F., Obim, E. N., \& Awara, F. (2014). Determinants of financial structure: Evidence from Nigerian quoted firms. Research Journal of Finance and Accounting, 5(16), 53-67.

10. Anarfo, E. B. (2015). Capital Structure and Bank Performance-Evidence from Sub-Sahara Africa. European Journal of Accounting Auditing and Finance Research, 3(3), 1-20.

11. Anginer, D., Mansi, S., Warburton, A. J., \& Yildizhan, C. (2015). Capital, Firm Reputation and the Cost of Debt. Munich Personal RePEc Archive.

12. Asiamah, N., Mensah, H. K., \& Oteng-Abayie, E. F. (2017). General, Target, and Accessible Population: Demystifying the Concepts for Effective Sampling. The Qualitative Report, 22(6), 1607-1621.

13. Atseye, F. A., Edim, N. O., \& Eke, F. A. (2014). Determinants of Financial Structure: Evidence from Nigerian Quoted Firms. Research Journal of Finance and Accounting, 5(16), 53-67.

14. Auerbach, A. J. (1985). Real Determinants of Corporate Leverage (Vol. I, pp. 301-324).

15. Baumohl, E., \& Lyocsa, S. (2009). Stationarity of time series and the problem of spurious regression.

16. Bhattarai, Y. R. (2016). Capital Structure and Firm Performance: Evidence from Nepalese Manufacturing Companies. Journal for Studies in Management and Planning, 2(3), 138-150.

17. Bibi, N., \& Amjad, S. (2017). The Relationship between Liquidity and Firms' Profitability: A Case Study of Karachi Stock Exchange. Asian Journal of Finance \& Accounting, 9(1), 54-67. 
"Relationship between Financial Structure and Financial Performance of Flag Carriers in Africa"

https://doi.org/10.5296/ajfa.v9i1.10600

18. Champion, R., Lenard, C. T., \& Mills, T. M. (1998). Demonstrating the Durbin-Watson Statistic. Journal of the Royal Statistical Spciety. Series D (The Statistician), 47(4), 643-644. https://doi.org/10.1111/1467-9884.00161

19. Chowdhury, R. (2019). Embarking on Research in the Social Sciences: Understanding the Foundational Concepts. VNU Journal of Foreign Studies, 35(1), 99-113.

20. Cole, C., Yan, Y., \& Hemley, D. (2015). Does Capital Structure Impact Firm Performance: An Empirical Study of Three U. S. Sectors. Journal of Accounting and Finance, 15(6), 57-65.

21. Covid-19's Impact on Sale And Leaseback Activity. (n.d.). Retrieved May 17, 2021, from https://www.iba.aero/insight/covid-19-and-impacton-sale-and-leaseback-activity/

22. Dada, F. B., \& Ukaegbu, B. (2015). The Pecking Order Theory: Evidence from Listed Firms in Nigeria. International Finance and Banking, 2(2), 72-84. https://doi.org/10.5296/ifb.v2i2.8679

23. Demirgüneş, K. (2016). The Effect of Liquidity on Financial Performance: Evidence from Turkish Retail Industry. International Journal of Economics and Finance, 8(4), 63-79.

https://doi.org/10.5539/ijef.v8n4p63

24. Dieleman, J. L., \& Templin, T. (2014). RandomEffects, Fixed-Effects and the within-between Specification for Clustered Data in Observational Health Studies: A Simulation Study. Plos One, 9(10), 1-17. https://doi.org/10.1371/journal.pone.0110257

25. Dunlock, H. L. (1993). Research Design: Descriptive Research. Journal of Pediatric Oncology Nursing, 10(4), 154-157.

26. Ehiedu, V. C. (2014). The Impact of Liquidity on Profitability of Some Selected Companies: The Financial Statement Analysis ( FSA ) Approach. Research Journal of Finance and Accounting, 5(5), 81-90.

27. Fama, E. F., \& French, K. R. (2002). Testing TradeOff and Pecking Order Predictions About Dividends and Debt. The Review OfFinancial Studies, 15(1), $1-33$.

28. Frank, M. Z., \& Goyal, V. K. (2003). Testing the Pecking Order Theory of Capital Structure, 67, 217248.

29. Ghazouani, T. (2013). The Capital Structure through the Trade-Off Theory: Evidence from Tunisian Firm. International Journal of Economics and Financial Issues, 3(3), 625-636.

30. Gil-Garcia, J. R., \& Puron-Cid, G. (2014). Using Panel Data Techniques for Social Science Research: an Illustrative Case and Some Guidelines. Ciencia
Ergo-Sum, 21(3), 203-216.

31. Githira, W. C., \& Nasieku, T. (2015). Capital Structure Determinants Among Companies Quoted in Securities Exchange in East Africa. International Journal of Education and Research, 3(5), 483-496.

32. Guemas, V., Auger, L., \& Doblas-Reyes, F. J. (2014). Hypothesis Testing for Autocorrelated Short Climate Time Series. Journal of Applied Meteorology and Climatology, 53(1), 637-651. https://doi.org/10.1175/JAMC-D-13-064.1

33. Hansman, R. J. (2014). Analysis of Impact of Aircraft Age on Safety for Air Transport Jet Airplanes.

34. Heinz, S., \& O’Connell, J. F. (2013). Air Transport in Africa: Toward Sustainable Business Models for African Airlines. Journal of Transport Geography, 31, 72-83. https://doi.org/10.1016/j.jtrangeo.2013.05.004

35. Hiestand, T. (2005). Using Pooled Model, Random Model And Fixed Model Multiple Regression To Measure Foreign Direct Investment In Taiwan. International Business \& Economics Research Journal, 4(12), 37-52.

36. Hill, T. D., Davis, A. P., Roos, J. M., \& French, M. T. (2019). Limitations of Fixed-Effects Models for Panel Data. Sociological Perspectives, 1-13. https://doi.org/10.1177/0731121419863785

37. Ibhagui, O. W., \& Olokoyo, F. O. (2018). Leverage and Firm Performance: New Evidence on the Role of Firm Size. North American Journal of Economics and Finance, 45(3), 57-82.

https://doi.org/10.1016/j.najef.2018.02.002

38. Imai, K., \& Kim, I. S. (2019). When Should We Use Unit Fixed Effects Regression Models for Causal Inference with Longitudinal Data? American Journal of Political Science, 63(2), 467-490. https://doi.org/10.1111/ajps. 12417

39. Ishak, N. M., \& Bakar, Y. A. (2014). Developing Sampling Frame for Case Study: Challenges and Conditions. World Journal of Education, 4(3), 2935. https://doi.org/10.5430/wje.v4n3p29

40. Islam, M., Akhtar, A., Munira, S., Khan, M. S., \& Murshed, M. M. (2018). Optimized Dickey-Fuller Test Refines Sign and Boundary Problems Compare to Traditional Dickey-Fuller Test. International Journal of Statistics and Probability, 7(5), 19. https://doi.org/10.5539/ijsp.v7n5p19

41. Jaleel, A., \& Olayiwola, B. (2017). Effect of Leverage on Firm Performance in Nigeria: A Case of Listed Chemicals and Paints Firms in Nigeria. Global Journal of Management and Business Research: Accounting and Auditing, 17(2), 14-24.

42. Javed, T., Younas, W., \& Imran, M. (2014). Impact of Capital Structure on Firm Performance: Evidence from Pakistani Firms. International Journal of 
Academic Research in Economics and Management Sciences, 3(5), 28-52.

https://doi.org/10.6007/IJAREMS/v3-i5/1141

43. Jensen, M. C. (2005). Agency Costs of Overvalued Equity. Financial Management, 34(1), 5-19.

44. Jensen, M. C., \& Meckling, W. H. (1976). Theory of the Firm: Managerial Behavior, Agency Costs and Ownership Structure. Journal of Financial Economics, 3(4), 305-360.

45. Jibran, S., Wajid, S. A., Waheed, I., \& Muhammad, T. M. (2012). Pecking at Pecking Order Theory: Evidence from Pakistan' s Non-financial Sector. Journal of Competitiveness, 4(4), 86-95. https://doi.org/10.7441/joc.2012.04.06

46. Jóźwiak, B. K., Marszalek, J., \& Sekula, P. (2015). Determinants of Debt-Equity Choice - Evidence From Poland. Emerging Markets Journal, 5(2), 1-8. https://doi.org/10.5195/emaj.2015.66

47. Kasomba, B. V., \& Omagwa, J. (2020). Financial Structure and Financial Performance of Domestic Commercial Airlines in Kenya. IOSR Journal of Economics and Finance (IOSR-JEF), 11(2), 57-66.

48. Kaya, H. D. (2014). The Impact of Leverage on Trade Firms' Profitability and Liquidity Measures. International Journal of Business and Social Science, 5(3), 66-70.

49. Kaźmierska-Jóźwiak, B., Marszałek, J., \& Sekuła, P. (2015). Determinants of Debt-Equity Choice Evidence From Poland. Emerging Markets Journal, 5(2), 1-8.

50. Kendirli, S., \& Kaya, A. (2016). The Evaluation of Working Capital in Airline Companies Which Proceed in BIST. Journal of Economic Development, Environment and People, 5(1), 3951.

51. Kirmi, P. N. (2017). Relationship Between Capital Structure and Profitability, Evidence From Listed Energy and Petroleum Companies Listed in Nairobi Securities Exchange. Journal of Investment and Management, 6(5), 97-102. https://doi.org/10.11648/j.jim.20170605.11

52. Kodongo, O., Mokoaleli-Mokoteli, T., \& Maina, L. (2014). Capital Structure, Profitability and Firm Value: Panel Evidence of Listed firms in Kenya. Munich Personal RePEc Archive.

53. Kraus, A., \& Litzenberger, R. H. (1973). A StatePreference Model of Optimal Financial Leverage. The Journal of Finance, 28(4), 911-922.

54. Kupolusi, J. A., Adeleke, R. A., Akinyemi, O., \& Oguntuase, B. (2015). Comparative Analysis Of Least Square Regression And Fixed Effect Panel Data Regression Using Road Traffic Accident In Nigeria. International Journal of Scientific \& Technology Research, 4(1), 42-52.

55. Lartey, V. C., Antwi, S., \& Boadi, E. K. (2013). The
Relationship between Liquidity and Profitability of Listed Banks in Ghana. International Journal of Business and Social Science, 4(3), 48-56.

56. Lukorito, S. N., Muturi, W., Nyang'au, A. S., \& Nyamasege, D. (2014). Assessing the effect of liquidity on profitability of commercial banks in Kenya. Research Journal of Finance and Accounting, 5(19), 145-153.

57. Machuki, V. N., \& Aosa, E. (2011). The Influence of the External Environment on the Performance of Publicly quoted Companies in Kenya. Business Administration and Management, 1(7), 205-218.

58. Mantin, B., \& Wang, J.-H. E. (2012). Determinants of Profitability and Recovery from System-wide Shocks: The Case of the Airline Industry. Journal of Airline and Airport Management, 2(1), 1-21.

59. Manyo, T. S., \& Ogwaku, V. N. (2013). Impact Of Liquidity On Return On Assets Of Firms: Evidence From Nigeria. International Journal of Management \& Information Technology, 6(3), 885-894.

60. Mhlanga, O., \& Steyn, J. N. (2017). Impacts of the Macro Environment on Airline Operations in Southern Africa. African Journal of Hospitality, Tourism and Leisure, 6(1), 1-15.

61. Miller, M. H. (1988). The Modigliani-Miller Propositions After Thirty Years. Journal of Economic Perspectives, 2(4), 99-120.

62. Modigliani, F., \& Miller, M. H. (1958). The Cost of Capital, Corporation Finance and the Theory of Investment. The American Economic Review, 48(3), 261-297.

63. Modigliani, F., \& Miller, M. H. (1963). Corporate Income Taxes and the Cost of Capital: A Correction. The American Economic Review, 53(3), 433-443.

64. Mouna, A., Jianmu, Y., Amalina, S., Havidz, H., \& Ali, H. (2017). The Impact of Capital Structure on Firms Performance in Morocco. International Journal of Application or Innovation in Engineering \& Management, 6(10), 11-16.

65. Muhammad, H., Shah, B., \& Islam, Z. (2014). The Impact of Capital Structure on Firm Performance: Evidence from Pakistan. Journal of Industrial Distribution \& Business, 5(2), 13-20.

66. Mulry, M. H., Bean, S. L., Bauder, D. M., Wagner, D., Mule, T., \& Petroni, R. J. (2006). Evaluation of Estimates of Census Duplication Using Administrative Records Information. Journal of Official Statistics, 22(4), 655-679.

67. Mummolo, J., \& Peterson, E. (2018). Improving the Interpretation of Fixed Effects Regression Results. Political Science Research and Methods, 1-7. https://doi.org/10.1017/psrm.2017.44

68. Musah, Y., \& Kong, Y. (2019). Leverage and financial performance: The correlational approach. International Journal for Innovative Research in 
Multidisciplinary Field, 5(4), 1-8.

69. Musau, V. M., Waititu, A. G., \& Wanjoya, A. K. (2015). Modeling Panel Data: Comparison of GLS Estimation and Robust Covariance Matrix Estimation. American Journal of Theoretical and Applied Statistics, 4(3), 185-191. https://doi.org/10.11648/j.ajtas.20150403.25

70. Musiega, M., Olweny, T., Mukanzi, C., \& Mutua, M. (2017). Influence of Credit Risk on Performance of Commercial Banks in Kenya. International Journal of Management and Commerce Innovations, 5(1), 299-308. https://doi.org/10.9790/5933-0803046775

71. Mwaniki, G., \& Omagwa, J. (2017a). Asset Structure and Financial Performance: A Case of Firms Quoted Under Commercial and Services Sector at the Nairobi Securities Exchange , Kenya, 8(4), 192-200.

72. Mwaniki, G., \& Omagwa, J. (2017b). Asset Structure and Financial Performance: A Case of Firms Quoted Under Commercial and Services Sector at the Nairobi Securities Exchange, Kenya. Research Journal of Finance and Accounting, 8(4), 192-200.

73. Myers, S. C. (1977). Determinants of Corporate Borrowing. Journal of Financial Economics 5, 5, 147-175.

74. Myers, S. C. (1984). The Capital Structure Puzzle. The Journal of Finance, 39(3), 575-592.

75. Nassar, S. (2016). The Impact of Capital Structure on Financial Performance of the Firms: Evidence From Borsa Istanbul. Journal of Business \& Financial Affairs, 5(2), 5-8. https://doi.org/10.4172/2167-0234.100017

76. Nurlaela, S., Mursito, B., Kustiyah, E., \& Hartono, S. (2019). Asset Turnover, Capital Structure and Financial Performance Consumption Industry Company in Indonesia Stock Exchange. International Journal of Economics and Financial Issues, 9(3), 297-301.

77. O’Connell, J. F., \& Warnock-Smith, D. (2012). Liberalization and Strategic Change in Air Transport: An Examination of Current and Future Variations in Tourist Traffic to and from Egypt Resulting from Policy Changes at EgyptAir. Tourism Economics, 18(4), 1-26. https://doi.org/10.5367/te.2012.0142

78. Ochieng, M. D., \& Ahmed, A. H. (2014). The Effects of Privatization on the Financial Performance of Kenya Airways. International Journal of Business and Commerce, 3(5), 10-26.

79. Ofoegbu, G. N., Duru, A., \& Onodugo, V. (2016). Liquidity Management and Profit Performance of Pharmaceutical Manufacturing Firms Listed In Nigeria Stock Exchange. International Journal of
Management Sciences and Business Research, 5(7), $1-13$.

80. Oghojafor, B. E. A., \& Alaneme, G. C. (2014). Nigeria Airways: The Grace and Grass Experience (A Case Study). International Journal of Business and Social Science, 5(13), 138-150.

81. Olakunle, A. O., \& Oni, E. O. (2014). Assessing the Impact of Asset Tangibility on Capital Structure : Choice for Listed Firms in Nigeria. Journal of Applied Economics and Business, 2(3), 5-20.

82. Onyenwe, N. I., \& Glory, I. (2017). Effect of Financial Leverage on Firm's Performance: A Study of Nigerian Banks (2006-2015). International Journal of Recent Scientific Research, 8(7), 18554 18564. https://doi.org/10.24327/IJRSR

83. Oracle Corporation. (n.d.). Chapter Five Working Capital and Current Asset Management. http://aviation.itu.edu.tr/img/aviation/datafiles/Lect ure Notes/Aviation Economics and Financial Analysis 20152016/Readings/Module 02/Vasigh et al.

84. Özcan, İ. Ç. (2019). Capital structure and firm performance: evidence from the airport industry. European Journal of Transport and Infrastructure Research, 19(3), 177-195.

85. Pinto, P., Hawaldar, I. T., Rahman, H. U., Rajesha, T. M., \& Sarea, A. M. (2017). An Evaluation of Financial Performance of Commercial Banks. International Journal of Applied Business and Economic Research, 15(22), 605-618.

86. Pires, H. M., \& Fernandes, E. (2012). Malmquist Financial Efficiency Analysis for Airlines. Transportation Research, 48, 1049-1055. https://doi.org/10.1016/j.tre.2012.03.007

87. Pontoh, W., \& Budiarso, N. S. (2018). Firm Characteristics and Capital Structure Adjustment. Investment Management and Financial Innovations, 15(2), $129-144$. https://doi.org/10.21511/imfi.15(2).2018.12

88. Pouraghajan, A., Malekian, E., Emamgholipour, M., Lotfollahpour, V., \& Bagheri, M. M. (2012). The Relationship between Capital Structure and Firm Performance Evaluation Measures : Evidence from the Tehran Stock Exchange. International Journal of Business and Commerce, 1(9), 166-181.

89. Raffalovich, L., \& Chung, R. (2014). Models for Pooled Time-Series Cross-Section Data. International Journal of Conflict and Violence, 8(2), 209-221.

90. Rahi, S. (2017). Research Design and Methods: A Systematic Review of Research Paradigms, Sampling Issues and Instruments Development. International Journal of Economics \& Management Sciences, 6(2), 1-5. https://doi.org/10.4172/21626359.1000403 
91. Rioja, F., \& Valev, N. (2011). Financial Structure and Capital Investment. Applied Economics, 1-11. https://doi.org/10.1080/00036846.2011.554376

92. Ross, I., \& Ytterfors, J. (2016). A Crude Awakening: Hedging Exposure in the Global Airline Industry.

93. Schlumberger, C. E. (2002). Implementation of the Yamoussoukro Decision on the Liberalization of Access to Air Transpor $t$ Markets in West and Central Africa.

94. Scott, J. H. (1976). A Theory of Optimal Capital Structure. The Bell Journal of Economics, 7(1), 3354.

95. Setiadharma, S., \& Machali, M. (2017). The Effect of Asset Structure and Firm Size on Firm Value with Capital Structure as Intervening Variable. Journal of Business \& Financial Affairs, 6(4), 4-8. https://doi.org/10.4172/2167-0234.1000298

96. Shim, G. T. G., Shakawi, A. M., \& Azizan, F. L. (2017). Relationship between Students' Diagnostic Assessment and Achievement in a Pre-University Mathematics Course. Journal of Education and Learning, 6(4), 364-371. https://doi.org/10.5539/jel.v6n4p364

97. Shyam-Sunder, L., \& Myers, S. C. (1999). Testing Static Trade-off Against Pecking Order Models of Capital Structure. Journal of Financial Economics, 51, 219-244.

98. Stiglitz, J. E. (1969). A Re-Examination of the Modigliani-Miller Theorem. The American Economic Review, 59(5), 784-793.

99. Svitlík, J., \& Poutník, L. (2016). Relationship between Liquidity and Profitability: Empirical Study from the Czech Republic. European Financial and Accounting Journal, 11(3), 7-24.

100.Teker, S., Teker, D., \& Güner, A. (2016). Financial Performance of Top 20 Airlines. Procedia - Social and Behavioral Sciences, 235(10), 603-610. https://doi.org/10.1016/j.sbspro.2016.11.035

101.Uremadu, S. O., \& Onyekachi, O. (2018). The Impact of Capital Structure on Corporate Performance in Nigeria: A Quantitative Study of Consumer Goods Sector. Current Investigations in Agriculture and Current Research, 5(4), 650-658. https://doi.org/10.32474/CIACR.2018.05.000217

102. Vatavu, S. (2014). The Determinants of Profitability in Companies Listed on the Bucharest Stock Exchange. Annals of the University of Petroşani, Economics, 14(1), 329-338.

103. Vătavu, S. (2015). The impact of capital structure on financial performance in Romanian listed companies. Procedia Economics and Finance, 32(15), 1314-1322. https://doi.org/10.1016/S22125671(15)01508-7

104.Warrad, L. (2014a). The Effect of Current Ratio on Jordanian Real Estate Sector's Net Profit Margin.
European Journal of Economics, Finance and Administrative Sciences, (63), 34-39.

105.Warrad, L. (2014b). The Effect of Current Ratio on Jordanian Real Estate Sector 's Net Profit Margin. European Journal of Economics, Finance and Administrative Sciences, (January), 35-39.

106. Waswa, C. W., Mukras, M. S., \& Oima, D. (2018). Effect of Liquidity on Financial Performance of the Sugar Industry in Kenya. International Journal of Education and Research, 6(6), 29-44. 